\title{
CLINICAL AND GENETIC APPROACH TO THE DYSMORPHIC CHILD
}

\author{
Luigi Tarani $^{1 *}$, Ginevra Micangeli ${ }^{1}$, Debora Rasio ${ }^{2}$, Silvia Ottombrino ${ }^{1}$, Natascia Liberati ${ }^{1}$, \\ Diego De Angelis ${ }^{1}$, Valentina Carito ${ }^{3}$, Antonio Greco ${ }^{4}$, Mauro Ceccanti ${ }^{5}$, Marco Fiore ${ }^{3 *}$ \\ ${ }^{1}$ Department of Pediatrics, Medical Faculty, Sapienza University of Rome, Italy \\ ${ }^{2}$ San Raffaele Roma, Open University, Rome, Italy \\ ${ }^{3}$ Institute of Cell Biology and Neurobiology, IBCN-CNR, Rome, Italy \\ ${ }^{4}$ Department of Sense Organs, Sapienza University of Rome, Italy \\ ${ }^{5}$ Centro Riferimento Alcologico Regione Lazio, Sapienza University of Rome, Italy
}

The child affected by a malformative syndrome represents a care challenge for the pediatrician. He is in fact the heart of the multidisciplinary team that has to manage the patient, trying to control the complications of his/her syndrome and promoting the correct psychophysical development. What we must not forget is that the pediatrician provides a continuous support to the child's family, assisting them from the diagnosis to the management of problems related to the syndrome. This encourages the continuous follow-up of these children remembering also that the pediatrician is fundamental in the clinical management of the syndrome and for facilitating the social integration of these children. Biomed Rev 2018; 29: $37-46$

Keywords: Rare disease, birth defect, genetic syndrome, diagnosis, pediatrician, treatment

\section{INTRODUCTION}

A birth defect, also known as a congenital disorder, is a condition present at birth regardless of its cause. Birth defects may result in disabilities that may be physical, intellectual, or developmental. The disabilities can range from mild to severe. The prevalence of birth defects is about $2-4 \%$ among live births $(1,2)$ which is the equivalent of about one patient out of 200 children with complex malformative syndromes and they are singularly considered rare diseases (3). It is calculated that the complex malformative syndromes are approximately 8000 , about a hundred of which have a prevalence between 1:2000 and 1:10.000; about 250 between $1: 10.000$ and $1: 100.000$, and about one thousand up to $1: 1$ million (4). The remaining 6500 represent sporadic cases. Therefore, because of the common genetic origin $(80 \%$ of the cases), of the manifestation in pediatric age and the concomitant association with a form of disability, the complex malformative syndromes represent an important problem of public health $(5,6)$.

Received 5 December 2018, revised 16 December, accepted 17 December 2018.

*Corresponding authors:

Prof. Luigi Tarani, Department of Pediatrics, Medical Faculty, Sapienza University of Rome, Italy

E-mail: luigi.tarani@uniroma1.it

Dr. Marco Fiore, PhD, Institute of Cell Biology and Neurobiology, IBCN-CNR Roma, Italy

E-mail: marco.fiore@cnr.it 
Table 1. The prevalence of the most frequent genetic syndromes.

\begin{tabular}{|l|l|l|l|}
\hline SYNDROME & PREVALENCE & SYNDROME & PREVALENCE \\
\hline Down & $1 / 800$ & Prader Willi & $1 / 10.000$ \\
\hline Klinefelter & $1 / 1.200$ & Trisomy 13 & $1 / 10.000$ \\
\hline Fra-X & $1 / 2.000$ & Angelman & $1 / 12.000$ \\
\hline Noonan & $1 / 2.000$ & Beckwith & $1 / 14.000$ \\
\hline Neurofibromatosis 1 & $1 / 3.000$ & Achondroplasia & $1 / 15.000$ \\
\hline Del22 (DiGeorge) & $1 / 3.000$ & Williams & $1 / 20.000$ \\
\hline Trisomy 18 & $1 / 5.000$ & Saethre Chotzen & $1 / 25.000$ \\
\hline Turner & $1 / 5.000$ & Poland & $1 / 30.000$ \\
\hline Tuberous sclerosis & $1 / 5.800$ & Kabuki & $1 / 32.000$ (Jap) \\
\hline VATER & $1 / 7.000$ & Smith Lemli Opitz & $1 / 40.000$ \\
\hline Arthogryposis multipla & $1 / 10.000$ & Wolf & $1 / 50.000$ \\
\hline CHARGE & $1 / 10.000$ & Apert & $1 / 70.000$ \\
\hline De Lange & $1 / 10.000$ & Crouzon & $1 / 80.000$ \\
\hline Spondilocostal dysostosis & $1 / 10.000$ & Cohen & $1 / 100.000$ \\
\hline Ehlers-Danlos & $1 / 25.000$ & Holt Oram & $1 / 100.000$ \\
\hline Marfan & $1 / 10.000$ & Sotos & $1 / 10.000$ \\
\hline
\end{tabular}

Indeed, in Italy the period which goes from 0 to 18 years, age known as childhood-adolescence, includes roughly 10 million people. The $15 \%$ of which, equivalent to 1.5 million, is represented by "children with special needs", affected by chronic diseases which require a very demanding medical approach (7). Among this group of patients, about half (8\% of the total, equal to 800.000 patients) are affected by diseases that involve disabilities, mental and physical defects that prevent social participation. These disabilities include different conditions such as: autism, infant cerebral palsy, consequence of tumors, but also diseases with elevated assistance demands as cystic fibrosis, thalassemia, spinal muscular atrophy and in the $0.5 \%$ of cases, equal to 50.000 patients, malformative syndromes like: Down, Cornelia de Lange and Noonan syndromes (8-10). These diseases can involve very serious clinical problems preventing personal autonomy, with important effects on assistance and social life. Hence in Italy in the last few years it was necessary to develop the branch of "Pediatrics of disability" which doesn't only involve the multispecialized medical approach, but is enhanced by multisectorial approaches which includes educational, scholastic and social features extended to the whole territory (11). Such an approach should be achieved through the creation of an assistance network which should integrate the reference group for rare diseases, which should create the assistance program and the family pediatrician, who should participate to the whole program (4).

What is the role of the family pediatrician in this integrated assistance network? For sure it's a fundamental and comprehensive role, which goes from the possibility of suspecting a disease to the management of its clinical requirements in collaboration with the reference group. In addition, the family pediatrician should identify the social needs of the child, understand the emergency and report the cases that need a rehabilitation $(12,13)$.

In other words, he could be the person responsible for the territory, who works in close touch with the family to facilitate the access to all the medical and social services (4). These services should completely satisfy the needs of the child and his family to facilitate the participation of the child to the social life in the best way possible (13). 


\section{THE PEDIATRICIAN MEETS THE CHILD WITH A MALFORMATIVE SYNDROME}

The pediatrician can do this in several ways:

1 When, among his patients, the pediatrician meets a newborn with a specific diagnosis. In this case the child already has a label, apart from the physical problems associated with chronic diseases, this can include specific aspects of the genetic syndromes. Among these there are the fear that the child will be discriminated because of his condition and the possibility of a difficult interaction between child and parents (13). Other important aspects are: the prognosis quoad vitam and quoad valetudinem, the implementation of an assistance program, the genetic consultation to investigate the family's history, the certification of rare disease and the contact with a parent's association to receive psychological support (4). Therefore, it's important that the pediatrician acquires as much information on the condition of the child especially on the variation of the medical situation, possible complications and follow-up (14). It would be useful to make sure the family has correctly understood the disease of the child and if not the pediatrician should refer the parents to the center which drew up the diagnosis (4). It would be also useful for the doctor to carry out a careful pediatric examination in order to treat the child like a normal patient, having periodic evaluations of height's and weight's growth by using, if available, the percentiles related to the specific syndrome. It would be wise to introduce a correct diet, for example hypocaloric in the Prader-Willi syndrome and hyper caloric in the Costello syndrome, and propose the optional vaccinations which don't have side effects from the beginning $(15,16)$. In fact, vaccinations are quite useful considering the high risk of respiratory infections in children with congenital heart disease, dysphagia/gastroesophageal reflux or restrictive pulmonary disease due to ribs abnormalities (17). The pediatrician must constantly follow in which way the family tackles the problem and the efficiency of the assistance network.

2 When the newborn arrives without a diagnosis, but instead with one or more major malformations (18-20). The pediatrician can be a valuable support to the family in the identification of the disease, knowing that even without a diagnostic label, the single problems can be faced in the same way.

3 When a normal child begins to show abnormalities in the psychomotor development or growth problems. The pediatrician should understand if the abnormality is isolated or associated with other malformations (21). For this reason, it's important that he prescribes blood test, radiological studies and functional tests like electroencephalogram, electrocardiogram, audiometric and oculist examination to reveal possible problems.

4 When he himself draws up the diagnosis of malformations or functional problems (visual, auditory, neurological, cardiac, renal) after the neonatal period. He should also document the clinical problems and his own diagnostic suspicion, directing the child to the geneticist. Apart from this he should explain why is sending the child to the geneticist and the possible diagnostic process $(18,20,22-26)$. At this point the pediatrician should inform the parents about the limits of the diagnostic process, in fact his suspicion could be erroneous or else it isn't possible to draw up a perfect diagnosis (13).

\section{WHEN AND HOW CAN THE SYNDROME BE SUSPECTED}

The clinical approach to the malformation syndromes presents peculiarities because of the clinical, etiological and pathological variations. The first thing is to present a diagnostic suspicion which precedes the clinical analysis, but demands especially attention on the part of the pediatrician (18).

The clinical elements which led to suspect a malformation syndrome are four: the presence of facial dysmorphisms such as hypertelorism, proptosis, oblique rima palpebrarum upwards or downwards, short nose with antiverse nostrils, long philtrum micrognathia and ears in a lower position (18). These details give the face a very particular aspect, in fact these patients don't resemble any member of the family.

The presence of major or minor malformations variably associated between themselves (18). In fact, an anorectal abnormality is syndromic in $50 \%$ of the cases, the cleft palate in the $30 \%$, an heart congenital disease or cataract in the $20 \%$ and a kidney malformation in the $15 \%$ (27). Some malformations are typical of specific syndromes such as tongue's hamartoma in the oro-facial-digital syndrome, the pulmonary stenosis valve in Noonan syndrome, the stenosis above aortic valve and the stenosis of pulmonary arteries in Williams syndrome, an heart disease and cleft palate in DiGeorge syndrome and the duodenal stenosis in Down syndrome $(8,10)$.

The presence of growth problems, either in excess (gigantism) or in default (dwarfism) or the presence of different between head and torso, torso and limbs, between the limbs themselves or between hemisomes (28). The abnormalities can also involve the skull such as macrocephaly (Sotos syndrome, hydrocephalous), and microcephaly which is evident at birth as in the Fetal Alcohol Spectrum Disorders (FASD; see Carito et 
al's "FASD in Pediatrics" in this volume of Biomedical Reviews) or in the Seckel syndrome, or else this can appear at a later period as in the Angelmann syndrome or in the Rett syndrome (29-32).

The presence of delayed psychomotor development, especially if associated with sensorial problems, is probably linked to a syndrome (21). If congenital abnormalities appear at birth it's the job of the neonatologist to assess them, but after that it will be responsibility of the pediatrician to identify defects in psychomotor development (33). The pediatrician will have also to consider major malformations in a child appearing normal at birth or else if the child had only one single malformation. Indeed, it is important that the pediatrician confirms that the abnormality is isolated or associated with a syndrome.

Then it will be the geneticist job to understand the etiology of the syndrome throughout a process composed of various elements which tend to complement each other, but which can also lead to diagnosis if considered separately. Therefore, there are two roads to follow in order to reach the diagnosis: the gestalt diagnosis and the analytical diagnosis. The first one, at a glance, consists in the immediate recognition of a well-known phenotype, and benefits itself of the association between memory and experience like recognizing a friend among a crowd. The diagnostic suspicion must then be confirmed by analytical instruments.

The analytical diagnosis, instead, uses the classical medical instruments such as: the family's history (genealogical tree of at least three generation to identify genetic diseases), the gestational history (threat abortion, quantity of amniotic fluid, growth and movements of the fetus, infections, abuse of alcohol and drugs, tobacco, prenatal diagnosis), neonatal history (asphyxia), physical examination, instrumental and clinical analyses associated to computer systems (POSSUM scoring system, London Dysmorphology Database) $(21,34)$.

Then it is up to the geneticist to define the case under observation, even utilizing further checks to find elements which are compatible with the disease, and prescribing genetic tests. The recent development of genetic testing, with an estimated detection rate of $40 \%$ for Next Generation Sequencing (NGS) and of $10 \%$ for microarrays analyses, allows to perform an etiological diagnosis in at least half of the known syndromes: Williams syndrome $95 \%$, Sotos syndrome $90 \%$, Noonan syndrome $80 \%$, Cornelia de Lange syndrome, Kabuki syndrome and CHARGE syndrome 70\%. (9, 10, 29, 35-37).

Table 2. The clinical and genetic characteristics of the most common genetic syndromes (7, 8, 13, 23, 25, 29, 31-46).

\begin{tabular}{|c|c|c|}
\hline SYNDROME OR ASSOCIATION & MAIN SYMPTOMS & GENETIC MUTATION \\
\hline Achondroplasia & $\begin{array}{l}\text { Poor growth with short arts, brachydactyly, } \\
\text { macrocephaly, and facial dysmorphisms }\end{array}$ & Genetic mutation in the FGFR3 in $4 p 16.3$ \\
\hline Neurofibromatosis 1 & $\begin{array}{l}\text { Cafe-au-lait spots, eye hamartomas (Lisch nodules), } \\
\text { neurofibromas, skeletal abnormalities, optic nerve glioma }\end{array}$ & $\begin{array}{l}\text { Mutation or deletion in the NF1 gene in } \\
17 q 11.2\end{array}$ \\
\hline Angelman & $\begin{array}{l}\text { Facial dysmorphisms, microcephaly, developmental delay, } \\
\text { language's problems, epilepsy }\end{array}$ & $\begin{array}{l}\text { Lack of function of } 15 q 11.2 \text { inherited from } \\
\text { mother }\end{array}$ \\
\hline Apert & $\begin{array}{l}\text { Craniosynostosis, facial dysmorphisms, syndactyly of } \\
\text { hands and foot }\end{array}$ & Mutation in the FGFR2 gene in $10 \mathrm{q} 26.13$ \\
\hline Bardet Biedl & $\begin{array}{l}\text { Obesity, mental disability, polydactyly post-axial, } \\
\text { nephropathy, hypogonadism, retinopathy }\end{array}$ & Mutations in 12 different genes \\
\hline Beckwith Wiedemann & $\begin{array}{l}\text { Overgrowth, umbilical hernia, omphalocele, } \\
\text { macroglossia, hemihyperplasia, visceromegaly }\end{array}$ & $\begin{array}{l}\text { Mutation or deletion of imprinted } \\
\text { genes in the area } 11 \mathrm{p} 15.5 \\
(\mathrm{H} 19, \mathrm{KCNQ} 10 \mathrm{~T} 1, \mathrm{CDKN} 1 \mathrm{C})\end{array}$ \\
\hline Crouzon & Craniosynostosis, facial dysmorphisms & Mutation in the FGFR2 gene in $10 \mathrm{q} 26.13$ \\
\hline Marfan & $\begin{array}{l}\text { Above height and disproportionately long limbs } \\
\text { (dolichostenomelia), ectopia lentis, aortic aneurysm or } \\
\text { dilatation, mitral valve prolapse }\end{array}$ & Mutation in the FBN1 gene in $15 q 21.1$ \\
\hline
\end{tabular}




\begin{tabular}{|c|c|c|}
\hline SYNDROME OR ASSOCIATION & MAIN SYMPTOMS & GENETIC MUTATION \\
\hline Prader-Willi & $\begin{array}{l}\text { Facial dysmorphisms, hypotonia, small hands and foot, } \\
\text { hypogonadism, obesity, hyperphagia, short stature, } \\
\text { neurodevelopmental delays }\end{array}$ & $\begin{array}{l}\text { Lack of function of } 15 q 11.2 \text { inherited from } \\
\text { father }\end{array}$ \\
\hline Rubistein-Taybi & $\begin{array}{l}\text { Facial dysmorphisms, growth's problems, } \\
\text { neurodevelopmental delays, wide and bifid thumbs or } \\
\text { toes }\end{array}$ & $\begin{array}{l}\text { Microdeletion in the } 16 p 13.3 \text { area, and } \\
\text { mutation in the CBBP gene in } 16 p 13.3 \text {, } \\
\text { mutation in the EP300 gene in } 22 q 13\end{array}$ \\
\hline Sotos & $\begin{array}{l}\text { Overgrowth, increased bone age, facial dysmorphisms, } \\
\text { delayed psychomotor development }\end{array}$ & $\begin{array}{l}\text { Mutation or deletion in the NSD1 gene in } \\
\text { the area } 5 \mathrm{q} 35 \text { in ( } 70 \% \text { of patients) }\end{array}$ \\
\hline Cri du chat & Microcephaly and mental disability & Deletion of a part of $5 p$ \\
\hline CHARGE & $\begin{array}{l}\text { Coloboma, congenital heart diseases, Choanal atresia/ } \\
\text { stenosis, lack of growth, genitals abnormalities, } \\
\text { hypoacusis, auricle abnormalities }\end{array}$ & $\begin{array}{l}\text { Mutation in the CHD7 gene in } 7 q 21.11 \text {, } \\
\text { mutation in the SEMA3E gene in } \\
8 q 12.1-q 12.2\end{array}$ \\
\hline Cornelia De Lange & $\begin{array}{l}\text { Facial dysmorphisms, lack of growth, } \\
\text { neurodevelopmental delays, hirsutism, small hands and } \\
\text { foot }\end{array}$ & $\begin{array}{l}\text { Mutation in the NIBL gene in } 5 p 13.1 \text {, } \\
\text { mutation in the SMC1L1 gene in } \\
\text { Xp11.22-p11.21, mutation in the SMC3 } \\
\text { gene in } 10 q 25\end{array}$ \\
\hline Di George & $\begin{array}{l}\text { Facial dysmorphisms, congenital heart disease, } \\
\text { hypocalcaemia, immune deficiency, neurodevelopmental } \\
\text { delays, cleft palate, suction's and swallowing's difficulties }\end{array}$ & Microdeletion of $22 q 11.2$ \\
\hline Holt-Oram & $\begin{array}{l}\text { Heart congenital diseases (or ECG abnormalities), } \\
\text { abnormalities of unilateral upper limb }\end{array}$ & $\begin{array}{l}\text { Mutation in the TBX5 gene in } 12 q 24.21 \\
\text { ( } 30 \% \text { of patients) }\end{array}$ \\
\hline Noonan & $\begin{array}{l}\text { Facial dysmorphisms, short height, pulmonary stenosis, } \\
\text { pterigium colli, pectus excavatum/carenatum }\end{array}$ & $\begin{array}{l}\text { Mutation in the PTPN1 } 1 \text { gene in } 12 \mathrm{q} 24.1 \\
\text { ( } 50 \% \text { of patients), mutation of RAS- } \\
\text { MAPK's pathway (KRASS, SOS1, NRAS, } \\
\text { RAF1 genes) }\end{array}$ \\
\hline Silver Russell & $\begin{array}{l}\text { Poor growth, asymmetry of limbs and face, facial } \\
\text { dysmorphisms, disproportion between braincase and } \\
\text { facial skeleton }\end{array}$ & $\begin{array}{l}\text { Maternal upd (uniparental disomy) of } \\
\text { chromosome } 7 \text { in the } 10 \% \text { patients, } \\
\text { hypometilation of } \mathrm{H} 19 \text { gene in } 11 \mathrm{p} 15 \\
\text { (30\% of patients) }\end{array}$ \\
\hline Treacher Collins & Facial dysmorphism, variability of clinical signs & $\begin{array}{l}\text { Mutation in the gene TCOF1 in } \\
5 q 32-q 33.1 \text {, mutation in the gene POLR1C } \\
\text { in } 6 p 21.1 \text {, mutation in the gene POLR1D } \\
\text { in } 13 q 12.2\end{array}$ \\
\hline Williams & $\begin{array}{l}\text { Facial dysmorphism, aortic stenosis, neurodevelopmental } \\
\text { delays, friendly character }\end{array}$ & Microdeletion 7q11.23 \\
\hline Wolf-Hirschorn & $\begin{array}{l}\text { Facial dysmorphism, short growth, neurodevelopmental } \\
\text { delays, eyes, renal and neurological malformations }\end{array}$ & Deletion of $4 p 16.3$ \\
\hline Goldenhar & $\begin{array}{l}\text { Asymmetry of the face, microtia or unilateral abnormality } \\
\text { of the auricle, preauricular appendages, epibulbar } \\
\text { dermoid and vertebral abnormalities }\end{array}$ & Clinical diagnosis \\
\hline VATER/VACTERL & $\begin{array}{l}\text { Vertebral and anal abnormalities, esophageal atresia } \\
\text { associated to tracheo-esophageal fistula, renal } \\
\text { malformations, heart congenital malformation }\end{array}$ & Clinical diagnosis \\
\hline
\end{tabular}




\section{THE ASSISTANCE AFTER THE DIAGNOSIS}

Immediately after the establishment of a diagnosis, etiological or genetic, or even in the absence of this the doctor takes control of the syndromic child; starting from the evaluation of his initial abilities (functional diagnosis) (53). At this point the pediatrician asks himself what the child will be able to do? What he will be able to do if he is helped? What can be corrected? What can be foreseen? All this to program the best clinical and rehabilitation follow-up (12). "The work of the pediatrician should come out of the clinic and be extended to all which is connected to the child's life" (54). Therefore he can intervene on the child, but he must also consider the economic, environmental and social situations of the family; furthermore the pediatrician can provide indications regarding medical education, he should also anticipate possible problems and perform preventive actions $(13,26)$.

For this he must be familiar with the syndrome having knowledge of the course, of possible complications, of emergencies and also the handling of the devices such as percutaneous endoscopic gastrostomy feeding, central line or tracheostomy (55, 56). The doctor should guarantee the correct nutritional intake of the child, by monitoring the intake of calories, the growth parameters and evaluating the possible vitamins and electrolytic deficits produced by feeding problems or drugs (57).

The supplements of vitamins and fluorine must follow the same guidance of the healthy children (58). Due to the risk of a possible impaired food deglutition the pediatrician must diagnose dysphagia and gastro-esophageal reflux, in order to begin a rehabilitation or a medical therapy, before directing the child to a specialist (12). The sleeping habits must be evaluated in order to direct the child to a specialist to solve problems (59).

Vaccinations must be done also on disabled children because they are more exposed to respiratory diseases, even if the vaccines coverage today is very low in this children (17). Finally, the pediatrician must assess if the family receive a proper social support, discover if the child is harmoniously integrated in the school environment, if he his carrying out his rehabilitation and if there is interaction between the facilities that assist him $(12,26)$. The pediatrician must guarantee the emergency's handling of the child with syndrome. This because these children enter the emergency room twice more than healthy children and are hospitalized much more easily (60). At the base of this, on one hand, there is the mistrust of the families towards the local clinics, but on the other hand, also the pediatrician is concerned about the fragility of the child.

Therefore, the knowledge of the course of the syndrome could facilitate the diagnosis of the complications and limit hospitalization to really deserving cases. In some of these syndromes there are specific symptoms that can lead to an immediate diagnosis such as chest pain in a boy with Marfan syndrome to suggest a pneumothorax or aortic dissection (38). While the abdominal pain in Williams syndrome should suggest an intestinal or a bladder diverticulitis or a mesenteric ischemia. On the contrary, in the Cornelia de Lange syndrome could suggest a volvulus due to intestinal malrotation and in Ehlers Danlos syndrome could indicate an intestinal rupture $(9,35)$. For example the headache in Williams syndrome and in Neurofibromatosis type 1 must orientate towards an hypertensive crisis or a cerebral stroke; while the sudden hypotonia/ hemiplegia in Down syndrome, achondroplasia and in the mucopolysaccharidosis must orient towards a trunk-encephalic compression from atlanto-axial instability $(8,35,52,61)$.

\section{CONCLUSION}

Even if the child with a malformative syndrome could not fully recovered, thanks to the abilities of the pediatrician he can be cured in the best way possible to improve the quality of the patient life and also for potentiating the child social integration (13).

\section{CONFLICT OF INTEREST STATEMENT}

The authors certify that they have no affiliations with or involvement in any organization with any financial interest in the subject matter discussed in this review article.

\section{ACKNOWLEDGEMENTS}

We apologize to the authors of many relevant articles that were not quoted here for reasons of brevity.

\section{REFERENCES}

1. Khoshnood B, Greenlees R, Loane M, Dolk H. Paper 2: EUROCAT public health indicators for congenital anomalies in Europe. Birth Defects Res Part A - Clin Mol Teratol 2011; 91:S16-22. DOI:10.1002/bdra.20776

2. Kirby RS. The prevalence of selected major birth defects in the United States. Semin Perinatol 2017; 41:338-344. DOI:10.1053/j.semperi.2017.07.004

3. Pogue RE, Cavalcanti DP, Shanker S, Andrade RV, Aguiar LR, de Carvalho JL, et al. Rare genetic diseases: update on diagnosis, treatment and online resources. Drug Discov Today 2018; 23:187-195. DOI:10.1016/j. drudis.2017.11.002 
4. von der Lippe C, Diesen PS, Feragen KB. Living with a rare disorder: a systematic review of the qualitative literature. Mol Genet Genomic Med 2017; 5:758-773. DOI:10.1002/mgg3.315

5. Wangler MF, Yamamoto S, Chao HT, Posey JE, Westerfield M, Postlethwait J, et al. Model organisms facilitate rare disease diagnosis and therapeutic research. Genetics 2017; 207:9-27. DOI:10.1534/genetics.117.203067

6. Taruscio D, Agresta L, Amato A, Bernardo G, Bernardo L, Braguti $\mathrm{F}$, et al. The Italian National Centre for rare diseases: Where research and public health translate into action. Blood Transfus 2014; 12:s591-605. DOI:10.2450/2014.0040-14s

7. Traisman ES. Care of the child with special needs. Pediatr Ann 2015; 44:522-525. DOI:10.3928/0090448120151111-01

8. Lee CF, Lin SS. The adaptation experience in a case of family stress generated by the birth of premature triplets. Hu Li Za Zhi 2005; 52:33-39. DOI:10.1186/s12929-0150138-y

9. Boyle MI, Jespersgaard C, Brøndum-Nielsen K, Bisgaard AM, Tümer Z. Cornelia de Lange syndrome. Clin Genet 2015; 88:1-12. DOI:10.1111/cge.12499

10. Bhambhani V, Muenke M. Noonan syndrome. Am Fam Physician 2014; 89:37-43.

11. Jaeger G, Röjvik A, Berglund B. Participation in society for people with a rare diagnosis. Disabil Health J 2015; 8:44-50. DOI:10.1016/j.dhjo.2014.07.004

12. An M, Palisano RJ. Family-professional collaboration in pediatric rehabilitation: A practice model. Disabil Rehabil 2014; 36:434-440. DOI:10.3109/09638288.2013.797510

13. Palisano RJ, Chiarello LA, King GA, Novak I, Stoner T, Fiss A. Participation-based therapy for children with physical disabilities. Disabil Rehabil 2012; 34:1041-1052. DOI:10.3109/09638288.2011.628740

14. Garrino L, Picco E, Finiguerra I, Rossi D, Simone $\mathrm{P}$, Roccatello D. Living with and treating rare diseases: Experiences of patients and professional health care providers. Qual Health Res 2015; 25:636-651. DOI:10.1177/1049732315570116

15. Lima VP de, Emerich DR, Mesquita MLG de, Paternez ACAC, Carreiro LRR, Pina Neto JM de, et al. Nutritional intervention with hypocaloric diet for weight control in children and adolescents with Prader-Willi Syndrome. Eat Behav 2016; 21:189-192. DOI:10.1016/j. eatbeh.2016.03.008
16. Hennekam RCM. Costello syndrome: An overview. Am J Med Genet 2003; 117C:42-48. DOI:10.1002/ ajmg.c. 10019

17. Esposito S, Cerutti M, Milani D, Menni F, Principi N. Vaccination coverage of children with rare genetic diseases and attitudes of their parents toward vaccines. Hum Vaccines Immunother 2016; 12:801-805. DOI:10.1080/2 1645515.2015.1086046

18. Jones KL, Adam MP. Evaluation and Diagnosis of the Dysmorphic Infant. Clin Perinatol 2015; 42:243-261. DOI:10.1016/j.clp.2015.02.002

19. Hennekam RC, Biesecker LG, Allanson JE, Hall JG, Opitz JM, Temple IK, Carey JC. Elements of morphology: General terms for congenital anomalies. Am J Med Genet Part A 2013; 161:2726-2733. DOI:10.1002/ajmg.a.36249

20. Esmer C, Urraca N, Carnevale A, Del Castillo V. Patient follow-up is a major problem at genetics clinics. Am J Med Genet 2004; 125:162-6. DOI:10.1002/ajmg.a.20303

21. Coughlin L. AAP releases guidelines on clinical evaluation of the child with mental retardation or developmental delays. Am Fam Physician 2007; 75:414-417. DOI:10.1542/ peds.2006-1006

22. Turchetta R, Conti G, Marsella P, Orlando MP, Picciotti PM, Frezza S, et al. Universal newborn hearing screening in the Lazio region, Italy. Ital J Pediatr 2018; 44:104. DOI:10.1186/s13052-018-0534-5

23. Ralli M, Greco A, Altissimi G, Tagliaferri N, Carchiolo L, Turchetta R, et al. Hyperacusis in children: A preliminary study on the effects of hypersensitivity to sound on speech and language. Int Tinnitus J 2018; 22:10-18. DOI:10.5935/0946-5448.20180002

24. Greco A, De Virgilio A, Rizzo MI, Tombolini M, Gallo A, Fusconi M, et al. Kawasaki disease: An evolving paradigm. Autoimmun Rev 2015; 14:703-709. DOI:10.1016/j. autrev.2015.04.002

25. Ralli M, Rolesi R, Anzivino R, Turchetta R, Fetoni AR. Acquired sensorineural hearing loss in children: current research and therapeutic perspectives. Acta Otorhinolaryngol Ital 2017; 37:500-508. DOI:10.14639/0392100X-1574

26. Mittal V. Family-centered rounds. Pediatr Clin North Am 2014; 61:663-670. DOI:10.1016/j.pcl.2014.04.003

27. Setó-Salvia N, Stanier P. Genetics of cleft lip and/or cleft palate: Association with other common anomalies. Eur J Med Genet 2014; 57:381-393. DOI:10.1016/j. ejmg.2014.04.003 
28. Graber E, Rapaport R. Growth and growth disorders in children and adolescents. Pediatr Ann 2012; 41:e65-e72. DOI:10.3928/00904481-20120307-07

29. Cole TRP. Sotos syndrome. Manag Genet Syndr Third Ed 2010; 2:769-786. DOI:10.1002/9780470893159.ch51

30. Katz DM, Bird A, Coenraads M, Gray SJ, Menon DU, Philpot BD, et al. Rett syndrome: Crossing the threshold to clinical translation. Trends Neurosci 2016; 39:100-113. DOI:10.1016/j.tins.2015.12.008

31. Margolis SS, Sell GL, Zbinden MA, Bird LM. Angelman syndrome. Neurotherapeutics 2015; 12:641-650. DOI:10.1007/s13311-015-0361-y

32. Memo L, Gnoato E, Caminiti S, Pichini S, Tarani L. Fetal alcohol spectrum disorders and fetal alcohol syndrome: the state of the art and new diagnostic tools. Early Hum Dev 2013; 89 (Suppl 1):S40-43. DOI:10.1016/S0378378213;70013-6

33. Reiss AL. Childhood developmental disorders: An academic and clinical convergence point for psychiatry, neurology, psychology and pediatrics. J Child Psychol Psychiatry Allied Discip 2009; 50:87-98. DOI:10.1111/ j.1469-7610.2008.02046.x

34. Practice Bulletin No. 124. Obstet Gynecol 2011; 118:730740. DOI:10.1097/AOG.0b013e3182310c6f

35. Pober BR. Williams-Beuren syndrome. $N$ Engl J Med 2010; 362:239-252. DOI:10.1056/NEJMra0903074

36. Cheon CK, Ko JM. Kabuki syndrome: Clinical and molecular characteristics. Korean J Pediatr 2015; 58:317-324. DOI:10.3345/kjp.2015.58.9.317

37. Hsu P, Ma A, Wilson M, Williams G, Curotta J, Munns CF, et al. CHARGE syndrome: A review. J Paediatr Child Health 2014; 50:504-511. DOI:10.1111/jpc.12497

38. Bitterman AD, Sponseller PD. Marfan syndrome: A clinical update. J Am Acad Orthop Surg 2017; 25:603-609. DOI:10.5435/JAAOS-D-16-00143

39. Das S, Munshi A. Research advances in Apert syndrome. J Oral Biol Craniofacial Res 2018; 8:194-199. DOI:10.1016/j.jobcr.2017.05.006

40. FRACS CGK. Bardet-Biedl Syndrome. Aust J Opthalmology 1984; 12:143-148. DOI:10.1111/j.1442-9071.1984. tb01143.x

41. Al-Namnam NM, Hariri F, Thong MK, Rahman ZA. Crouzon syndrome: Genetic and intervention review. $J$ Oral Biol Craniofacial Res 2019; 9:37-39. DOI:10.1016/j. jobcr.2018.08.007

42. Milani D, Manzoni FMP, Pezzani L, Ajmone P, Gervasini
C, Menni F, et al. Rubinstein-Taybi syndrome: Clinical features, genetic basis, diagnosis, and management. Ital J Pediatr 2015; 41:4. DOI:10.1186/s13052-015-0110-1

43. Espirito Santo LD, Moreira LMA, Riegel M. Cri-DuChat syndrome: Clinical profile and chromosomal microarray analysis in six patients. Biomed Res Int 2016; 2016:5467083. DOI:10.1155/2016/5467083

44. Binder G, Begemann M, Eggermann T, Kannenberg K. Silver-Russell syndrome. Best Pract Res Clin Endocrinol Metab 2011; 25:153-160. DOI:10.1016/j. beem.2010.06.005

45. Srinath S. Treacher collins syndrome. J Pharm Sci Res 2014; 6:247-250. DOI:10.1055/s-0032-1320066

46. Wieczorek AD. Wolf-Hirschhorn syndrome. In: MP Adam, HH. Ardinger, RA Pagon, SE Wallace, LJH Bean, K Stephens, A Amemiya, editors. GeneReviews. Seattle (WA): University of Washington, Seattle; 1993-2018.

47. Bogusiak K, Puch A, Arkuszewski P. Goldenhar syndrome: current perspectives. World J Pediatr 2017; 13:405-415. DOI:10.1007/s12519-017-0048-z

48. Solomon BD. VACTERL/VATER association. Orphanet J Rare Dis 2011; 6:56. DOI:10.1186/1750-1172-6-56

49. Goldfarb CA, Wall LB. Holt-Oram syndrome. J Hand Surg Am 2014; 39:1646-1648. DOI:10.1016/j.jhsa.2014.02.015

50. Ornitz DM, Legeai-Mallet L. Achondroplasia: Development, pathogenesis, and therapy. Dev Dyn 2017; 246:291-309. DOI:10.1002/dvdy.24479

51. McDonald-McGinn DM, Sullivan KE, Marino B, Philip N, Swillen A, Vorstman JAS, et al. 22Q11.2 Deletion syndrome. NatRev Dis Prim 2015; 1:15071. DOI:10.1038/nrdp.2015.71

52. Korf BR. Neurofibromatosis. Handb Clin Neurol 2013; 111:333-340. DOI:10.1016/B978-0-444-52891-9.00039-7

53. Basel D, McCarrier J. Ending a diagnostic Odyssey: Family education, counseling, and response to eventual diagnosis. Pediatr Clin North Am 2017; 64:265-272. DOI:10.1016/j.pcl.2016.08.017

54. Castellanos JG, Walker M, Poggio D, Pourkashanian M, Nimmo W. Modelling an off-grid integrated renewable energy system for rural electrification in India using photovoltaics and anaerobic digestion. Renew Energy 2015; 74:390-398. DOI:10.1016/j.renene.2014.08.055

55. Vervloessem D, van Leersum F, Boer D, Hop WCJ, Escher JC, Madern GC, et al. Percutaneous endoscopic gastrostomy (PEG) in children is not a minor procedure: risk factors for major complications. Semin Pediatr Surg 2009; 18:93-97. DOI:10.1053/j.sempedsurg.2009.02.006 
56. Al-Samri M, Mitchell I, Drummond DS, Bjornson C. Tracheostomy in children: A population-based experience over 17 years. Pediatr Pulmonol 2010; 45:487-493. DOI:10.1002/ppul.21206

57. van Goudoever JB, Carnielli V, Darmaun D, Sainz de Pipaon M, Braegger C, Bronsky J, et al. ESPGHAN/ ESPEN/ESPR guidelines on pediatric parenteral nutrition: Amino acids. Clin Nutr 2018; 37:2309-2314. DOI:10.1016/j.clnu.2018.06.945

58. Leaf AA. Vitamins for babies and young children. Arch Dis Child 2007; 92:160-164. DOI:10.1136/adc.2006.109066
59. Hoban TF. Sleep disorders in children. Contin Lifelong Learn Neurol 2013; 19:185-198. DOI:10.1212/01. CON.0000427206.75435.0e

60. McCandless SE, Brunger JW, Cassidy SB. The burden of genetic disease on inpatient care in a children's hospital. Am J Hum Genet 2004; 74:121-127. DOI:10.1086/381053

61. Joseph AW, Joseph SS, Francomano CA, Kontis TC. Characteristics, diagnosis, and management of EhlersDanlos syndromes: A review. JAMA Facial Plast Surg 2018; 20:70-75. DOI:10.1001/jamafacial.2017.0793 